\title{
Profesor Kazimierz Bartoszyński
}

\begin{abstract}
Kosowska Ewa, Profesor Kazimierz Bartoszyński (1921-2015) [Professor Kazimierz Bartoszyński (1921-2015)]. „Przestrzenie Teorii” 23. Poznań 2015, Adam Mickiewicz University Press, pp. 311-315. ISBN 978-83-232-2920-9. ISSN 1644-6763. DOI 10.14746/pt.2015.23.23.

Prof. Kazimierz Bartoszyński was one of the most respected theoreticians of literature in Poland. He worked closely with the Institute of Literary Research of the Polish Academy of Sciences. The period of Professor Bartoszyński's greatest activity as a researcher coincided with the time when he was fascinated with structuralism, but his interests went far beyond these methodological issues. The author of this memoir, who was the Professor's doctoral student, portrays him through the prism of their conversations on scholarly topics and her private relationship with Mr. and Mrs. Bartoszyński, which lasted for many years.
\end{abstract}

Nie można wspominać kogoś, kto odszedł bezpowrotnie, nie podejmując jednocześnie próby zrozumienia jego roli we własnym życiu. W każdym wspomnieniu jest cień tej przewrotnej zmiany perspektywy, dzięki której podmiotowość Zmarłego powoli przestaje samodzielnie istnieć w przestrzeni społecznej, a zaczyna się przeistaczać w prezentystyczną z ducha konstrukcję autorstwa wspominających, w mozaikę ich przypadkowych wrażeń i celowych przemyśleń, w bezwiedne niekiedy przekłamanie, w którym to, co było, miesza się z tym, co mogłoby być, a bilans rzeczywistych dokonań Tego, który odszedł, wspiera wypadkową Jego - widzianych z zewnątrz - intencji i możliwości, planów i realizacji, racjonalnych ocen i emocjonalnych werdyktów. Pamięć tych, którzy wspominają, jest zagospodarowywana przez drobiazgi i błahostki, fragmentaryczne obrazy, anegdoty, ślady przypadkowo zasłyszanych sformułowań przeszkadzają w rekonstrukcji istoty myśli twórczej Tego, który nie może już prostować błędnych ścieżek interpretacji.

Wspominanie Profesora Kazimierza Bartoszyńskiego, wspominanie oficjalne, bo związane z upublicznieniem prywatnej wizji Jego postaci, nie jest łatwe i wymaga odpowiedzialności. W moim odczuciu Profesor pożegnał się zbyt szybko, mimo wszystko zbyt niespodziewanie, bym dzisiaj mogła potraktować jego życie jak zamkniętą kartę, jak zestawienie zalet (wszak zmarli wad nie mają), które teraz wypada podsumować, opisać, zamknąć w mniej lub bardziej udatnym tekście, w zbiorze okolicznościowych formuł i konwencjonalnych określeń. A jednocześnie zdaję sobie sprawę z tego, że nie można polemizować z rytmem kulturowych konwencji, które wprawdzie wspominającym dają chwilę na oswojenie nowej 
rzeczywistości, ale jednocześnie domagają się szybkiej reakcji: czym innym jest upamiętnianie Zmarłego w kilka tygodni lub miesięcy po jego odejściu, a czym innym odwoływanie się do jego dokonań już po ukończeniu oficjalnego okresu żałoby.

Kazimierz Bartoszyński należał do grona osób mi najbliższych, był nie tylko promotorem mojej pracy doktorskiej i recenzentem habilitacji (w tamtych latach nietaktem ze strony Rady Wydziału byłoby wykluczenie promotora $\mathrm{z}$ udziału w dalszych etapach naukowej drogi ucznia; dziś, jak wiadomo, właśnie ten udział może skutkować oskarżeniem o swoisty nepotyzm). Był moim nauczycielem, kolegą, sąsiadem, jedną $\mathrm{z}$ osób, z którymi mogłam rozmawiać swobodnie, wymieniać się pomysłami, snuć naukowe plany, dzielić wątpliwościami. Po pierwszych latach znajomości, w których wyznaczany przez niego krąg lektur ukierunkowywał nasze dyskusje na problemy stricte naukowe, nastąpił długi okres rozmów pozornie towarzyskich, lekkich, a przecież nie wolnych od poważnych intelektualnych wyzwań. Ja stosunkowo szybko odeszłam od problematyki teoretycznoliterackiej, która z kolei Jemu była najbliższa. Nieporadna próba dookreślenia granic Jego filozofii literatury była praktycznie moim pożegnaniem z zagadnieniami, które Jemu były najbliższe. Wielokrotnie naszym późniejszym spotkaniom towarzyszył song o swoistej zdradzie wobec Mistrza, ale jednocześnie Kazimierz - wtedy już Kazik, Kazio, „oswojony” i zaprzyjaźniony - z właściwą sobie wyrozumiałością dawał do zrozumienia, że wprawdzie ma do mnie żal o to odstępstwo, ale jednocześnie szanuje mój wybór. Ten szacunek dostrzegałam między innymi w próbach wprowadzenia do rozmów tematyki antropologiczno-kulturowej: Kazik pytał o książki, o wyznaczniki metodologiczne, o terminy. Nie było w Nim fałszywego wstydu: jeśli czegoś nie wiedział, a chciał poznać, potrafił pytać bez skrępowania. Ta bezpośredniość sprawiała, że z czasem traktowałam Go niemal jak rówieśnika, chociaż w rzeczywistości był starszy od moich rodziców. Odpowiadając na Jego wnikliwe pytania, często porządkowałam własne myślenie. On, słuchając odpowiedzi, szukał w niej inspiracji do rozwiązania jakiejś kwestii, która Go aktualnie nurtowała. Ostatnimi czasy chodziło o przyszłość humanistyki, a szczególnie filologii. Bliski mi mariaż literaturoznawstwa $\mathrm{z}$ antropologią kulturową, początkowo trudny dla Niego do zaakceptowania, z czasem zyskał uznanie. Nasze rozmowy, prowadzone jesienią i zimą 2014 roku, były już zdominowane przez to właśnie „nowe otwarcie”: Kazik zaczął w antropologii upatrywać szansy na reinterpretację własnych studiów nad powieścią historyczną. Snuł w tym zakresie ambitne plany, chociaż zdawał sobie sprawę z radykalnego odpływu własnych sił. Więc w naturalny sposób zakładał, że może liczyć na moją pomoc. 
Znałam Kazimierza przez ponad czterdzieści lat; los zetknął mnie z Nim na początku mojej naukowej drogi i pozwolił mi towarzyszyć Mu do końca. Widywaliśmy się systematycznie, chociaż niezbyt często - początkowo, gdy te relacje miały charakter zależności typu mistrz - uczennica, ich częstotliwość była chyba większa, z czasem intensywność kontaktów zmalała do kilku - niekiedy kilkunastu spotkań w roku. Ale każda rozmowa z Nim miała swój ciężar gatunkowy. Był świetnym rozmówcą, ale też przede wszystkim znakomitym słuchaczem. Potrafił niezwykle silnie koncentrować się na przedmiocie rozmowy - do tego stopnia, że gdy jakieś okazjonalne wydarzenia zewnętrzne kazały mu przerwać wątek, by rozstrzygnąć problem lub skomentować bieżącą sprawę - czynił to bez widocznych trudności i przy pierwszej okazji wracał do przerwanego, zasadniczego toku rozmowy. Tę podzielność uwagi i umiejętność powrotu do przerwanego toku myślenia zachował do końca. Z czasem zaczął tak ukierunkowywać dyskusję, by celowo nawiązać do ustaleń, które pojawiły się w trakcie któregoś z poprzednich spotkań. Myślał syntetycznie; bardzo szybko budował własną wizję rozwiązania danego zagadnienia i konsekwentnie ją legitymizował, starannie dobierając odpowiednie argumenty. Był przywiązany do własnych koncepcji, ale nigdy nie były to więzy tak silne, by uniemożliwiały dopuszczenie do głosu innej interpretacji. Przeciwnie - chętnie słuchał, wdawał się w polemiki, ale i pozwalał na polemizowanie z sobą. Nie dotyczyło to jedynie rozmów prywatnych przeciwnie, wypowiadając się publicznie, zawsze potrafił „właściwe dać rzeczy słowo". Charakteryzował się ogromnym autorytetem, ale nigdy nie wykorzystywał go do obrony określonych rozwiązań tylko dlatego, że były Jego autorstwa. Znakomici uczestnicy słynnych IBL-owskich konferencji teoretycznoliterackich z pewnością zapamiętali go jako „żelaznego" dyskutanta, którego głosu słuchało się z uwagą i z którego opinią praktycznie każdy się liczył. Bowiem opinie wygłaszane przez Kazimierza Bartoszyńskiego zawsze były wyważone, przemyślane, zawsze nawiązywały do koncepcji autora referatu bądź artykułu i zawsze pogłębiały jakiś aspekt teoretyczny lub poszerzały autorską interpretację o nowe, interesujące przykłady. Był erudytą, miał dociekliwy umysł, znakomitą pamięć i ogromną wiedzę. Bez trudu odwoływał się do najwłaściwszych koncepcji filozoficznych i teoretycznych, celnie przywoływał odpowiednie przykłady z literatury światowej. Jako czytelnik-koneser był odbiorcą wybrednym i niełatwo było zaspokoić jego gusta. Literatury polskiej specjalnie nie cenił, chociaż w twórczości kilku pisarzy dostrzegał artystyczny potencjał. Byli wśród nich między innymi Fryderyk Skarbek, Henryk Rzewuski, Józef Ignacy Kraszewski, Hanna Malewska, Teodor Parnicki, Witold Gombrowicz. Nie lubił Sienkiewicza. Dosyć często spieraliśmy się w tej 
kwestii; Kazik nie zawsze chciał zrozumieć moją koncepcję antropologii literatury, aczkolwiek w ostatnich naszych rozmowach pojawił się wątek nostalgiczny: „miałaś rację, należało zająć się tą antropologią, to jest jakaś szansa dla literaturoznawstwa". Ta jego otwartość była budująca, mimo że do końca praktycznie pozostał wierny zainteresowaniom, które wybrał na wstępie swojej naukowej drogi: był przede wszystkim teoretykiem literatury, na którego koncepcję silnie oddziaływał strukturalizm, chociaż pogłosy fenomenologii (był przecież uczestnikiem seminarium Romana Ingardena) były silnie obecne w jego myśleniu. Próbował z nimi walczyć - zawsze świetnie wiedział, „kim” i „czym” myśli, ale nigdy nie był zwolennikiem zmiany metodologicznej dla samej zmiany. Starał się raczej dobierać metodę do interesującego go zagadnienia, chociaż jako teoretyk podejmował też refleksję nad problemami metametodologicznymi. Pisał niewiele; Jego żywiołem była rozmowa. Pielęgnował w tej materii tradycję sokratejską i negocjował prawdę w dialogu. Dopóki stan zdrowia Mu na to pozwalał, brał czynny udział w naukowych dyskusjach publicznych, ale i nie stronił od spotkań towarzyskich, na których mógł wymienić poglądy z kolegami i przyjaciółmi. Obracał się w kręgu koryfeuszy warszawskiej i krakowskiej polonistyki; wielu z nich szczerze Go lubiło i podziwiało, chociaż nie każdy dzielił Jego poglądy i przekonania. Zapewne dlatego tak bardzo wstrząsnęło Nim odejście Henryka Markiewicza i Janusza Sławińskiego, dwóch przyjaciół chyba najważniejszych w jego zawodowym życiu, z których jeden, od wielu lat naukowo milczący, nadal jest obecny $\mathrm{w}$ teorii literatury, a drugi do ostatniej chwili stał na straży logicznej spójności literaturoznawczych wywodów. Pożegnanie z nimi nie było łatwe; moge powiedzieć, że w ostatnich rozmowach Kazimierz często wracał do fenomenu swoistości każdego $\mathrm{z}$ nich, jakby chciał zrozumieć, dlaczego to właśnie ich odejście podkopuje jego nadwątlone siły.

Nigdy nie był człowiekiem fizycznie mocnym, odkąd pamiętam, zawsze towarzyszyły mu kłopoty zdrowotne. Miewał depresyjne nastroje, łatwo tracił wiarę w sens własnej pracy, zamykał się w sobie. Niewątpliwie zbawienny wpływ na poprawę jego psychofizycznej kondycji miało małżeństwo. Regina, czyli Pani Profesor Lubas-Bartoszyńska, potrafiła zdroworozsądkowo rozstrzygać rozmaite filozoficzne dylematy, wprowadziła w Jego życie ład i porządek, z oddaniem czuwała nad Jego zdrowiem i nie pozwoliła, żeby zaniechał naukowej pracy. Dyskutowała z nim, spierała się, przepisywała jego teksty, dbała o publikacje. Kazimierz w codziennym życiu był sybarytą i smakoszem, a ona potrafiła zadbać o jego wygody i zadowolić podniebienie - chociaż jej codzienna troska o rozmaite diety budziła niekiedy jego frustracje i głębokie niezadowole- 
nie („dobry rosół, ale nie ma selera” - skomentował ostatnio starania Żony). Byli dobranym małżeństwem i Kazimierz niewątpliwie wiele jej zawdzięczał.

Jego odejście pozostawiło nadal niezabliźniony ślad.

Przechodząc obok ich domu, a czynię to często, każdorazowo przypominam sobie jakieś drobne zdarzenia z przeszłości, przywołuję strzępy rozmów, dźwięk głosu, charakterystyczne gesty. Trudniejsze do odtworzenia są meandry myśli, tok argumentacji, reakcje na naukowe propozycje. Kazimierz nie budował w rozmowach zwartego systemu teoretycznego, raczej sprawdzał pewne pomysły, „przegadywał” argumenty, upewniał sam siebie odnośnie do słuszności przyjmowanych rozwiązań. Reginę niekiedy irytowała ta jego skłonność; słusznie przestrzegała przed skutkami wielogodzinnych dyskusji. Dla Kazimierza nie miało większego znaczenia, czy coś zostało powiedziane, czy napisane - ważne, że było dostrzeżone i sformułowane, zamknięte w słowie, zweryfikowane przez choćby jednego odbiorcę. Zadowolony $\mathrm{z}$ efektu rzadko podejmował trud utrwalania tych przemyśleń. Ona jednak rozumiała znaczenie publikacji i starała się motywować Go do żmudnej pracy. Nie zawsze się to udawało, z czasem pogodziła się chyba z Kazikowymi preferencjami. Albo po prostu była nazbyt zmęczona utrapieniami codzienności, żeby jeszcze dopingować niesfornego Męża. A Mąż, zwłaszcza w ostatnich latach, unikał pisania pod byle pretekstem. Preteksty miał zresztą niebagatelne, a najważniejszym była postępująca utrata wzroku. Czytał za pomocą wyrafinowanych konstrukcji optycznych, ale pisanie przekraczało Jego możliwości. Dyktował. Jednak sensem jego istnienia była konwersacja, żywy kontakt z drugim człowiekiem. Niebywała sprawność towarzyska pozwalała mu nawiązywać więź porozumienia niemal z każdym, ale prawdziwą przyjemność sprawiały $\mathrm{Mu}$ rozmowy, z których wynikało coś ważnego, coś, co pogłębiało zrozumienie świata i co pozwalało znaleźć sposób na opisanie specyfiki tego rozumienia. Hermeneutyka stosowana na co dzień była pasją Jego życia, była kluczem do pokonywania trudności, stwarzanych przez materię literatury.

Wdzięczna Mu jestem za to, że mogłam częściowo uczestniczyć w tych zmaganiach. 